\title{
LEGITIMATION OF THE REFERENDUM - THE STANDARD MECHANISM OF PARTICIPATORY DEMOCRACY
}

\author{
Laviniu Florin Ușvat \\ Attorney - Attorneys Association in Arad, Romania \\ Lecturer PhD,’Vasile Goldiș” Western University Arad, Romania \\ E-mail: usvatlaviniu@gmail.com
}

\begin{abstract}
The referendum is a multidimensional instrument, attested and practiced worldwide, considered to be a compulsory feature of democracy, provided it is used under strict lawfulness. The purpose of putting it into practice is to know the sovereign will of the people, expressed by vote, on a particular issue subject to its decision-making capacity. Following the referendum process, and in the case of referendum forms, such as the legislative or decision-making process, the referendum generates the obligation for the governing authorities to implement the decision adopted by the people. It is certain that the people's response to the referendum question materializes a decision that emanates from the people, and which benefits in this way of increased legitimacy. Legitimacy is a concept that unleashes the force of the referendum, the result of which is imposed on everyone, the minority who voted against, and the governors. Legitimacy gives an institutional sense to the referendum, being an immanent part of the entire referendum process. It comes from the principle of the sovereign will of the people, which once expressed, is imposed on all the executive factors that must apply it. Legitimacy is both an intrinsic quality of the referendum and its effect, as it gives force to the outcome and justifies any political, legislative or administrative action or inaction. If the referendum process were deprived of legitimacy, or the resulting decision would be denied of this supreme attribute, then the referendum would be an artificial institution, empty of content, virtually useless.
\end{abstract}

Keywords: democracy, people sovereignty, referendum, legitimacy, force of referendum result.

\section{Democracy through referendum.}

In theory as well as in practice, contemporary democracies are attracted by the spectrum of direct popular actions as an alternative to all types of representative systems. Direct popular action, in its various forms, among which the most is the popular referendum, serves to fortify the democratic element and provides a real means of supporting democratic constitutional systems. But if the dose is too high, the absolutely necessary balance is jeopardized [1].

In addition to the four classical categories of democracy [2], the exercise of sovereignty has also given rise to some subcategories of democracy, identified at the doctrinal level, such as democracy through referendum. This was defined as a democracy in which the free people (demos) decided directly on the controversial issues through the referendum [3]. Starting from its intrinsic nature and purpose, 
the referendum is a concrete product of the sovereignty of the people, or more accurately, the decision taken as a result of the referendum process emanates in the most authentic way possible from the people. In this respect, the referendum appears as a means of reaching the goal, namely the greatest participation of the citizens in the exercise of sovereignty.

Democracy through referendum is not and should not be perceived as an ideal substitute for other forms of democracy; its purpose is to allow the overthrow of the will of the governors by the will of the people [4], on certain specific points, in accordance with the principle of the supremacy of the sovereignty of the people. In fact, no matter what forms they can embrace, democracy is not just a form of government, but a set of principles (Woodrow Wilson).

Democracy through the referendum is the part of direct democracy - the immediacy of the adopted decision - by removing the intermediaries, that is, the representatives of the people in the institutions that govern a state. That would be its great advantage. However, in the doctrinal polemic it was stated that democracy by referendum excludes the other characteristic of direct democracy: the interaction of the decision-makers, that is, of the citizens participating in the referendum. This remark is fair and reveals a weak point of the institution. In this way, it appears as a direct democracy of the isolated individuals, not of the polemic participants; the actor of the referendum behaves as an electoral actor, in the sense that he acts alone, without participating in debates. Thus, the issuance of an informed vote, after prior information obtained by each citizen for the purpose of expressing a clear vote, is greatly endangered [5]. Simple debate on the issues of the referendum in the media cannot fill the energy of dialogue.

The mainstay of democracy through referendum is that, by its nature, it can also manifest in the universe of representative democracy, transforming it. From the perspective of representative democracy, the referendum appears to be a constant danger, but in reality the fear of a referendum is a false matter. In fact, in a representative democracy, it can only compete with the representative principle that is the foundation of this form of democracy, and mitigate its application.

It is inappropriate to regard the referendum as a competitor of popular representation, and in this optics, an unhealthy instrument of government [6]. It has the purpose and may play a helpful role even for representative democracy, serving government as an instrument of legitimizing a decision, or with a cynical note, as a means of taking responsibility for making a certain decision.

Democracy through referendum respects the maximum that defines pure democracy as "the people's rule by the people, for the people" - Abraham Lincoln, because the referendum is the instrument by which the people themselves decide. However, in order to have this character, the citizen must be aware of the mission entrusted to him, not perceive his call to vote as a burden but as an opportunity to 
exercise his political and civic responsibilities. However, neither referendum democracy excludes the issue of dimensions. Its main defect is that most people have the right to hegemony on the minority, which is of absolute character, because for every matter in part, the majority will win everything, excluding negotiations and compensations between the two parties. In this respect, it was stated that "since each referendum decision is an individual decision and taken independently, it cannot be balanced by exchanges, adjustments or corrections of the problems that have arisen. In short, the objection is that democracy through referendum is a structure to maximize conflict, which not only represents the perfect incarnation of the systematic tyranny of the majority, but also the most lacking in its intelligence expression. "[7]

In fact, this philosophical-ethical problem of the fratricidal conflict between the majority and the minority is intrinsic to democracy, and this millenary conflict has not yet even found justifications, much less resolution, or even finding solutions for concluding it. From our point of view, this "tyranny" of the majority over the minority is a pseudo-problem, and its propagation is bad for the concept of democracy. In fact, democracy means the decision of those involved (CarlFriedrich von Weizsaecker), whatever the manifestation.

Democracy through a referendum still has a peculiarity, that it gives the citizen who exercises it actively other competencies than the elective. These competences may relate to the sanctioning of an act adopted by a representative state body; In this case, the people's vote is the result of a referendum which may be mandatory if the intervention of the people is an indispensable condition for the entry into force of the act or, optionally, if the popular sanction is emerging on the basis of the request of a state body (parliament, head of state, government, or a part of the people). In these cases, depending on the legal nature of the act subject to the acceptance or disobedience of the people, the referendum may be constitutional, legislative, financial and administrative. The referendum is constitutive when its outcome is legally binding on all democratic actors; it is advisory when popular opinion does not impose direct obligations on them.

The existence of this subspecies of democracy is today indisputable for the simple reason of the very large number of referendums that are held all over the world. However, we prefer the classic approach to this form of democracy, which at didactic level is within semi-direct democracy.

\section{Legitimacy of the referendum.}

The referendum involves citizen participation in making a decision, but it is only the technical-procedural means by which that decision is adopted. The effect of the referendum, thereby understanding the force of its outcome, is also an important criterion for classification within the institution, with three species being 
universally admitted: the consultative referendum, the result of which is only an element of appreciation for the governors; the indicative referendum, which merely sums up to the governors an objective, the choice of means to attain it remains at their discretion; the decisional referendum, which produces binding legal effects and immediate enforcement [8].

The referendum process has the purpose of getting an answer to a concrete question about which people are asked to express their choice. Through this process, the people acquire the status of decision-maker, and depending on the nature of the referendum, the variety of which is limited only to its binding or consultative nature, the decision adopted by the majority vote is mandatory (in the case of the decisional referendum), and this only obliges the governors to take into account the popular vote, which is not imposed to them (in the case of the consultative referendum).

Naturally, direct popular decisions enjoy greater legitimacy than those taken by representatives, and the referendum becomes a reliable tool for expressing the will of the people as clearly as possible. Promoters of the referendum have a decisive mission in determining the outcome, respectively its success or failure, being proven that the outcome of the referendum is influenced by the initiator.

Starting from the actual exercise of semi-direct democracy, it can be ascertained that its component part - the referendum - is the one that clearly differentiates it from other forms of democracy. "In a democracy, the only possible source of legitimacy is the will of the sovereign people. From this point of view, the referendum and the initiative have a great advantage, because they are the most direct means of ensuring the will of the people "[9]. This doctrinal opinion underlines the relationship between the legitimacy of semi-direct democracy and the concept of self-government, and the link between the two is created by the referendum.

Starting from the idea that citizens are aware that the decisions they make themselves are the most legitimate, at the expense of those taken by elected representatives, political leaders or other elites, the partisans of the referendum appreciate that this reality is an essential and characteristic virtue of this institution. The consequence of this syllogism is the legitimacy enjoyed by the referendum, more precisely the decision expressed behind it.

Despite the adversity of the representative regime towards semi-direct democracy, the referendum can be used, and it is used by it to shirk responsibility when deciding on a crucial issue. It has been argued that the referendum should be regarded as an ingenious means by which a complicated situation can be solved, which needs to be implemented only when absolutely necessary, or when a decision must be taken as serious, so unpredictable in Consequences [10]. In such a situation, if the people's representatives would hesitate to assume moral 
responsibility (for example, to participate in a war, or to conclude agreements with international lending institutions that would have led to the implementation of a system of strong austerity measures - the referendum Greek in 2015 being a caseschool), an alternative could be to transfer responsibility to the people, to decide on a referendum.

Thus, it can be noticed that adjacent to the function of legitimacy, the referendum still has a specific feature: the people's innocence for the decision made. In other words, irrespective of the outcome of the referendum vote and the consequences it entails, people cannot be held accountable. The cause of this irresponsibility lies in its status as supreme super-institutional state organ.

Considering the proliferation of referendum types, whose legislation demonstrates the legislator's effort to strengthen the source of the legitimacy of certain laws or measures, referendum-derived forms arise in different constitutional orders. For example, through the French constitutional review of 23 July 2008, Art. 11 of the Constitution in the sense of regulating a legislative referendum on indirect minority initiative, an innovation for the French constitutional order, and quite rarely encountered, given the colossal importance it can have and the negligible impact. More specific, in the type form provided by art. 1 The President of the Republic may, at the proposal of the Government or of the two Chambers of Parliament, published in the Official Gazette, submit to the referendum any draft law on the organization of public powers, on economic, social or environmental policy reforms or on the ratification of a treaty, which, without contradicting the Constitution, will influence the functioning of the institutions. After the constitutional review, at par. 3 of art. 11 the same power to trigger the referendum, in the same areas of reference, is granted to one fifth of the members of the parliament, supported by $10 \%$ of the citizens enrolled in the electoral lists [11]. The two ways of initiating the referendum and adopting a law according to the outcome of the referendum, in areas of greatest importance to a state, denotes the concern of the French political power to legitimize certain laws or legislative reforms by calling for a referendum. This constitutional regulation attests to the existence of legitimacy as the finality of the referendum, a quality that it attributes to the popular decision, whatever it is.

All these ideas converge towards the definite connection between the referendum process and the resulting decision, which benefit from a much-graded quality legitimacy. This decision is the direct emanation of the people and their sovereignty.

\subsection{The concept of legitimacy}

First of all, referendum consultations have a remarkable mission: they not only make a decision, but very likely that decision will be considered more legitimate 
and unanimously accepted than a decision made indirectly by parliaments [12]. "The referendum maintains a direct link between the nation and its representatives; He encourages the political education of citizens, he likes to vote for ideas and texts; It makes them understand the issues on which the prosperity of the country and its own interest depend; He maintains public activity and civic spirit. He gives the laws all their power. It helps to defeat resistance and remove obstacles. "[13] This reflection gives a general view of the importance of the referendum, and although the legitimacy it gives is not specified, this supreme quality of the decision adopted after a referendum comes from the interpretation of the text.

According to the definition given by the Romanian Language Explanatory Dictionary, legitimate means that something is founded on the law, something that is justified by law, something that is recognized by law. From this definition it follows that legitimacy is a direct effect of the force of the law, and the referendum gives it a specific force, because the decision is the emanation of the will of the people.

Legitimacy implies an ethical exigency: For power, it demands the search for justification. "(...) Power is legitimate only if it takes precedence over a title other than force; The refusal to resort to force is the one that inspires any search for legitimacy and gives it the ethical dimension (...) the legitimacy (is) superior if the power is faithful to the values that transcend it. " [14]

The legitimacy of the referendum has its source in the Constitution and the law, but it also derives from the fundamental principle of equality between citizens and the equality of chances between the partisans and opponents of the proposal. Any harm to equality leads to the moral failure of the referendum. This is an intrinsic legitimacy. The incorporation into the Constitution of this institution must be interpreted as a great advance towards pure democracy, being a first sign of a break with representative democracy. In our opinion, the legal norms which establish and promote the referendum in various cases, and fix the procedure of deployment must have at least a rank of law, and in the hierarchy of laws, they must have an organic level, as stipulated in the Constitution of Romania in art. 73 par. 3 lit. D. This character should not be given to those technical and detailed rules necessary for the gradual implementation of the procedure itself, rules which may also come from the executive, and they can also be regulated in the form of simple government ordinances.

Regarding the regulation of the referendum at constitutional level, it is necessary and appropriate for both the proper reception by the people of its role and the legal aspect, because in this way this institution would acquire supreme legal force, being safeguarded. In other contexts, the complicated and complex character of the constitutional amendment procedures is known, irrespective of the constitution of the country that I use as an example. "I believe that a constitution that makes the 
referendum a means of government is made for the people, not the people for a constitution" [15]. Therefore, according to this vision, it is absolutely imperative that a democratic constitution foresee in its body the institution of the referendum, and that would be one of the proofs of its origin from the people, which would never deny the natural right to self-government.

In any case, the referendum is by its legal nature an instrument in the service of democracy, and of legitimacy as well. So, the referendum gives legitimacy to the form of government, in general to democracy, but unfortunately even the dictatorship (examples of referendums organized by totalitarian states were quite common), in the sense of maintaining or abandoning it [16], but also by reference decisions Are taking that form of government.

In this way, the extrinsic legitimacy of the referendum is used, either to know and apply the will of the people, or to strengthen the decision of the governors through the decision of the people. Unfortunately, in the latter case, the referendum becomes a manipulation tool, playing a role that takes advantage of the governors. The referendum as a form of legitimation of an essential decision for the future of the state or of an organized society appears as a serviceable institution. Popular consultations on EU membership, or in the case of Greenland, for getting out, are the expression of a fundamental conquest of democracy. The same significance also has the ratification of a new Constitution by the people, because of which the French tradition is favourable to the referendum, and which the Swiss law imposes. Instead, the constitutional right has not once confronted the issue that arises when the constitution in force does not provide for the referendum, but the parliament creates the legal framework, through an ad hoc law, for organizing and conducting a referendum on a pre-set theme [17 ].

At the level of the European Union, skeptics talk about a democratic legitimacy deficit of the whole structure, which is progressively affected by the accession of the new member countries. The referendum is talked about as a viable solution for giving legitimacy to important decisions taken within the Union.

\subsection{The extrinsic legitimacy of the referendum according to the main forms of referendum}

The most popular and traditional form of referendum is the constitutional referendum, being divided into constituent and reassessing. The constituent referendum is the ratification of a constitution by the people and has the role of giving rise to a new constitutional order different from the previous one. So, the people's decision to adopt a new constitution, expressed in a referendum, gives legitimacy to the constitution. Reassessing referendum is the one that changes, in whole or in part, the constitution in force. So, for the purpose of their revision, multiple constitutions regulate the obligation to organize a referendum by which 
the people are questioned whether or not they accept the constitutional modification in the form proposed to it. For example, the Japanese Constitution adopted on $5^{\text {th }}$ May 1947 regulated in art. 96 a rigid three-stage constitutional review procedure, of which the central one involves organizing a referendum by which the people express their will in relation to the parliamentary constitutional amendment initiative [18]. So, in constitutional matters, the last word always has the people who manifest their sovereign power through the referendum. Therefore, the acceptance by referendum of the revised constitution gives it the necessary legitimacy for its existence.

The legislative referendum is the most expressive form of association of the people in the legislative process, because it is called upon to express its opinion on a bill that is to be adopted eventually. In short, he is subjecting a law bill, in the broad sense of the notion, to the referendum vote of citizens responding by simple "yes" or "no". If that text is adopted, then it will enjoy greater legitimacy, because it emits directly from the people. In this case, the positive result of the referendum gives legitimacy to a text of the law (not the constitution, as in the case of the special legitimacy conferred by the result of the referendum on the new constitution or the amendment of the existing one).

The third spread category of referendum is the consultative one, whose particularity dissociates it from the above-mentioned categories: the result of the referendum does not have to be observed, it has no binding legal force for the authorities. At first glance, it could be said that this type of referendum would not have any legitimacy. And yet, even though the authorities are not formally linked to the outcome of the vote, which is non-decision-making, the organization of a consultative referendum responds to a need for legitimacy in a given field, which also directs authorities [19]. This category of referendum does not have an isolated role, but its regulation is necessary because the consultative referendum allows to identify the legitimacy issues that a political system (an example of a Greek referendum organized on a specific subject for political purposes but in a very problematic economic and fiscal context), and has the purpose of knowing the opinion of the people. There are rare examples when the will of the people has been neglected by state authorities, which, when consulted, have questioned democratic legitimacy.

At the level of the European Union, the principle of democratic legitimacy of the entire European construction is determined, by the way of functioning which, briefly, implies that an authority can exercise competences and take measures that have a binding effect on the law subjects concerned. In this way conceived the system, the exercise of that power must be legitimate. It is not only theoretical, but also illusory, to obtain legitimacy of decisions taken at Union level only through national procedures, given the postponement of Community procedures by national 
structures [20]. In this way, the European Union is in a position to compensate for a shortage of democracy that is hard to fulfil. The specificity of the European referendums is that, at the current stage of Community law, they can only be organized on the basis and within the national law of the Member States or the aspirants. Both the original and the constitutional treaties do not enshrine the referendum as an instrument of the community decision-making process. In fact, national referenda on European issues have gained a sense of regularity and periodicity that gives it a certain extent. So the European referendum is meant to give legitimacy to the decisions adopted following referenda on European issues, whether it was accession to the European Union (accession referendum) or the intensification of the integration process through the formal review of the founding treaties (referendum on Integration), or by accepting the entry of a new member state into the Union (enlargement referendum) [21].

In public international law, the referendum is a means of achieving the right of peoples to dispose of themselves. It is necessarily linked to the international status of a particular territory, making the difference between the annexation, union (association), or secession referendum [22]. Unlike domestic referendums that are the fruit of the sovereignty of the people, the international ones are organized for the purpose of fulfilling an international obligation created by the effect of a treaty, or by the effect of a decision issued by an international organization constituted by a treaty [23]. So, in short, an international referendum is meant to legitimize the birth of a state with cut off territorial boundaries.

Finally, the local referendum is organized in a territorial subdivision of a national state and concerns a matter that almost exclusively concerns that community. The local / regional referendum is and will be heavily influenced by the political and administrative system in which it is legislated and manifests itself (it can be noticed that the legislators, for example the Romanian or the Italian ones, paid much attention to the part which regulates the local referendum by creating a whole system of substantial and procedural rules, different from one system to another); the local level of the referendum is illustrative to show to what extent there is a political dialogue between citizens and local authorities. However, in order to render it more effective, it is crucial that there is a guarantee that municipalities will respect the outcome of the local or regional referendum [24]. The legitimacy of the local referendum is given by the sovereign will of the local people expressed on a particular issue of local interest (building a stadium, contracting public loans for the development of the infrastructure of the respective administrative-territorial unit, selling, leasing, renting public property of considerable value Or of strategic importance for the municipality, environmental issues, etc.). Typically, the local referendum is the one that influences the adoption or rejection of a major project or decision for the local community and its intrinsic purpose is to attribute legitimacy 
to the public decision. It represents an interconnection between the local authorities with administrative tasks and the sovereign will of the local nationals, materialized as a result of the referendum; Through the effects of a local referendum, it puts the local people in the position of superior power and, among other things, is also a means of controlling the actions of elected or appointed local representatives.

\section{Conclusions}

The role that the referendum plays in modern democracies is controversial. It can be a means for governors to ensure greater legitimacy, or it can be a way of developing the civic consciousness of the people, who find themselves involved in decision-making processes that can have a great extent: the adoption of a constitution. But it can also be a danger of tyranny by the majority and weakening of the representative government.

In any case, the referendum represents a global phenomenon, known to the peoples, much practiced by some of them in order to know and implement their own decision on a point on which they are called to the referendum. The result of the referendum, which takes the form of an exact decision, propagates having implanted legitimacy, immanent ownership. In this way, legitimacy is presented both as a function of the entire referendum process, but especially of the resulting decision, as well as an effect of the latter. This bivalence gives the legitimacy of the referendum the power to observe and implement the result of the referendum vote; At the same time, the legitimacy makes this result acceptable to both the minority who "lost" the referendum and to the governors, who are obliged to take very seriously the decision of the people, and to find the technical-legislative modalities of its application (the case of the consultative referendum) or to execute it immediately (in the case of the referendum).

Finally, denying legitimacy as a primordial appropriation of the referendum, or as an immanent function of it, is to turn the referendum into a simple tool emptied of any substance. However, in order for legitimacy to be attested, it is imperative that the referendum process be carried out with strict observance of the law, otherwise it is false.

\section{Bibliography:}

[1] Friederich C.J., Constitutional Government and Democracy, Ginn Publishing House, Boston, 1950, p. 808

[2] Direct Democracy, when people are self-governed; Representative democracy, when power, which cannot be exercised directly by the people or the nation, requires representation, delegation to act in the name of the power-holder, the people; Within it, the people delegate their sovereignty to some principals, who have the capacity to decide on their behalf; Semi-representative democracy, a form of government resulting from the 
mitigation of the negative consequences of ultra-representativeness; semi-direct democracy, characterized by the coexistence of representative democracy with direct democracy.

[3] G. Sartori, The re-interpreted democracy theory, translated by D. Pop, Polirom Publishing House, 1999, p. 119

[4] J.-C. Cabanne, Référendum et légitimité, in "Référendum et démocratie", Presses de l'Université des Sciences sociales de Toulouse Publishing House, Toulouse, 1998, p. 71

[5] Idem

[6] S. Belaid, Essai d'une théorie générale du référendum, in "Référendum et démocratie", Presses de l'Université des Sciences Socieles de Toulouse Publishing House, Toulouse, 1998 , p. 37

[7] G. Sartori, cited work., p. 122

[8] F. Hamon, Hamon Francis, Le référendum. Étude comparative, L.G.D.J. Publishing House, Paris, 1995, p. 15-16

[9] Geoffrey de Q. Walker, The People's Law, Collingwood Publishing House, Victoria, Center for Independent Studies, 1987, p. 50

[10] V. Constantin, Public International Law, West University Publishing House, Timişoara, 2004, p. 18

[11] For details, S. Diémert, Le référendum d'initiative minoritaire dans l'art. 11, révisé, de la Constitution, in Revue française de Droit constitutionnel, 77, 2009, p. 55-97

[12] D. Butler, A. Ranney, Referendums. A Study in Practice and Theory, Washington DC, American Entreprise Institute, 1978, p. 226

[13] Vincent Auriol, President of the French Republic (1947-1954), Hier ... demain, vol. II, Charlot Publishing House, Paris, 1945, p. 202

[14] J. Rivero, Consensus et légitimité, in "Pouvoirs - Revue française d'études constitutionnelles et politiques", n. 5, 1978, Paris

[15] André Malraux, Antimémoire, Gallimard Publishing House, Paris, 1967, p. 160

[16] An example of this is Chile and its famous dictator, accused of crimes against humanity, Augusto Pinochet Ugarte. The 1981 state constitution, written by Pinochet's military junta and approved by popular referendum, stipulated that at the end of Pinochet's 8 -year term, the junta would elect a candidate and the voters would be called upon to support or reject it. Junta chose Pinochet, but the referendum of October 5, 1988 had an unexpected result: Of $92 \%$ of the participants, $55 \%$ responded with no. Pinochet accepted the outcome, and in 1989, after a democratic election, which had been disputed among several candidates, Chile had a new president

[17] This is the case of Belgium in 1950 on the return of King Leopold III to the throne, and the case of Great Britain in 1975 on the remaining in the European Economic Community.

[18] For details, É. Seizelet, Le référendum d'intérêt national en matière constitutionnelle au Japon, in Revue française de Droit constitutionnel, 85/2011, p. 53-40

[18] F. Esposito, Vers a nouveau pouvoir citoyen? Des référendums nationaux au référendum européen, Université de Genève, Bruulant-Académie Publishing House, Geneva, 2007, p. 96

[19] Épiney A., Le référendum européen, in 'Le référendum européen: actes du colloque international de Strasbourg, 21-22 février 1997', Andreas Auer et Jean-François Flauss 


\section{JOURNAL OF LEGAL STUDIES}

"Vasile Goldiș" Western University of Arad

Ușvat, L.V. (2017)

Legitimation of the referendum. The Standard Mechanism of Participatory Democracy

(éd.); Université de Genève, Centre d 'études et de documentation sur la démocratie directe, Institut européen [et] Université Robert Schuman de Strasbourg, Centre d'études internationales et européennes, Institut des hautes études européennes, Bruylant Publishing House, Bruxelles, 1997, p. 292

[20] For details, L. F. Uşvat, European Referendum, in the International Academic Conference on Law, Politics \& Management, p. 92, The International Institute for Academic Development, Batumi, Georgia, 2015

[21] P. de Visscher, Le plébiscite international, in La participation directe du citoyen à la vie politique et administrative", Bruylant Publishing House, Bruxelles, 1986, p. 139

[22] Idem

[23] Celotto A., Regional and Local People Consultation through Referendum, Perspectives on Federalism, Vol. 4, Issue 1, 2012, p. 12 